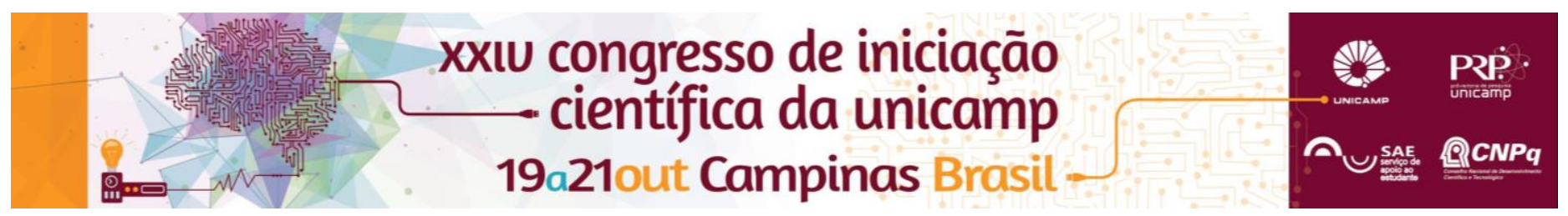

\title{
O Movimento Revolucionário 8 de Outubro (MR-8): da luta armada á luta pelas liberdades democráticas, 1971-1976.
}

\author{
Jefferson Godoy Athaydes*, Claudio Henrique de Moraes Batalha.
}

\begin{abstract}
Resumo
Este projeto teve como objetivo analisar a saída da luta armada de uma organização comunista, o Movimento Revolucionário 8 de Outubro, na Ditadura Militar e a adoção de uma nova tática de luta política, a bandeira das liberdades democráticas. Para tanto, demonstramos como a organização apresentava seus ideais de 1969 a 1971, a crise e o racha causados pela autocrítica à luta armada em 1972, e como o grupamento divulgava seus novos ideais a partir de 1974, apresentando mudanças e continuidades em seu discurso e entrando em conflitos com outros coletivos comunistas.
\end{abstract}

\section{Palavras-chave:}

Ditadura Militar, MR8, liberdades democráticas.

\section{Introdução}

O Movimento Revolucionário 8 de Outubro (MR-8) foi um dos principais grupamentos comunistas que praticaram a luta armada nos anos 1960 e 1970, durante a ditadura militar. Uma de suas ações mais famosas foi o sequestro do embaixador americano em 1969, em conjunto com a Ação Libertadora Nacional.

Após esse sequestro a ação da repressão de intensifica e a organização tem diversos membros mortos e exilados. Teria sido no exílio o início do debate em que a organização decide recuar da prática armada, assim como a adoção de uma nova tática de luta política, a defesa da bandeira das liberdades democráticas.

Partindo do princípio em que autores como Daniel Aarão Reis ${ }^{1}$ consideram que os comunistas, nos anos 1960 , não eram democráticos, enquanto outros, como Mario Almada Grabois ${ }^{2}$, consideram que as discussões sobre a democracia não eram desconhecidas para a Esquerda Revolucionária, procuramos nos atentar justamente para como esse tema aparece na documentação (não só como tema central, mas também subjetivamente). Daí, seria possível verificar a mudança do discurso da organização tanto relativo à democracia quanto outros temas que permeavam o Brasil dos anos 1970.

\section{Resultados e Discussão}

A documentação básica para o estudo desse período são os documentos internos produzidos pela organização, como informes, cartas e boletins, assim como periódicos publicados em conjunto a outras organizações. Durante os anos da luta armada, de 1969 a 1972, foi priorizada a análise das linhas políticas da organização: a Linha política de abril de 1969 e a Orientações para a prática de janeiro de 1971. Nesses documentos pudemos reafirmar as características trazidas por Aarão Reis Filho, ou seja, de que a organização era antidemocrática e, de certo modo, se apresentava como um grupo de elite, reunindo a vanguarda capaz de liderar as massas, as únicas que poderiam realizar a revolução. Realização essa só possível sob a direção da vanguarda, sem margens para a autonomia própria dos trabalhadores.
Consideramos, indo na direção do que afirma Denise Rollemberg ${ }^{3}$, que o exílio seria o momento e o lugar de traumas e choques, mas também o de renovação. $O$ contato com outras culturas e outros sistemas políticos, assim, foi fundamental para a mudança política da organização. O racha do MR-8, em 1972, pode ser considerado como um conflito entre uma ala propensa a repensar a atuação da organização, de acordo com uma nova conjuntura, e outra que considera a autocrítica como um desvio e um reformismo aos moldes do PCB.

Por fim, durante o governo Geisel o grupamento publica no exílio, em conjunto com a Ação Popular MarxistaLeninista e a Política Operária, a revista Brasil Socialista. Ela é fundamental para analisarmos as transformações que se dão na linha política da organização, sendo influenciadas, acima de tudo, pelas eleições de 1974.

\section{Conclusões}

O estudo da transformação da atuação de uma organização comunista no período da distensão política do governo Geisel nos ajuda a compreender o próprio processo de redemocratização. O MR-8 não tinha por objetivo retornar aos moldes da democracia pré-1964, ao contrário, almejava conquistar as liberdades democráticas para criar a consciência da classe trabalhadora, preparando-a para a futura Revolução. A mudança pelo qual passou a organização foi, dessa forma, somente uma mudança tática: as liberdades democráticas serviriam para que o objetivo estratégico fosse alcançado, ou seja, a Revolução Socialista.

\section{Agradecimentos}

Agradeço ao CNPq pelo financiamento à esta pesquisa; ao meu orientador Prof. Dr. Claudio H. M. Batalha pela atenção e paciência e ao Arquivo Edgar Lauenroth pela guarda e disponibilização dos documentos utilizados.

\footnotetext{
1 AARÃO REIS FILHO, Daniel. A revolução faltou ao encontro: os comunistas no Brasil. São Paulo: Brasiliense: CNPQ, 1990.

2 GRABOIS, Mario Almada. A luta desarmada: a esquerda revolucionária e o debate da questão democrática nos anos 1970. Dissertação de mestrado em ciência política UFRJ, Rio de Janeiro, 2007.

3 ROLLEMBERG, Denise. Exílio: entre raízes e radares. Rio de Janeiro: Record, 1999.
} 